\title{
Genetic Linkage between the Loci for Colour Blindness and Duchenne Type Muscular Dystrophy
}

\author{
ALAN E. H. EMERY
}

\author{
From Manchester University Department of Medical Genetics, The Royal Infirmary, Manchester 13
}

Duchenne type muscular dystrophy is a condition which begins in infancy or early childhood, and is characterized by progressive muscle weakness leading to death in the late teens or early twenties (Walton and Nattrass, 1954). This type of muscular dystrophy has been variously referred to as 'pseudohypertrophic muscular dystrophy' (Bell, I948), 'progressive muscular dystrophy of childhood' (Stephens and Tyler, 1951), and 'rapidly progressive muscular dystrophy of young boys' (Stevenson, 1953). This type of muscular dystrophy will be referred to here as Duchenne type muscular dystrophy, in agreement with the suggestion made by Walton (1955, 1957) that this is probably the best designation for that type of muscular dystrophy which affects young boys and is inherited as an $\mathrm{X}$-linked recessive trait.

Evidence for $\mathrm{X}$-linkage has been derived from several sources. In the few cases where affected males have lived long enough to have children, their sons have all been unaffected (Walton, 1955; Morton and Chung, 1959), though it is possible that these more benign cases represent a different disease, sometimes referred to as the Becker type of $\mathrm{X}$-linked muscular dystrophy (Becker, 1962). It has also been suggested that since several'affected children are known to have had the same mother but different fathers (Milhorat and Wolff, 1943; Walton, 1955) this may be used as evidence for $\mathrm{X}$-linkage. However, this does not exclude autosomal inheritance with limitation to the male sex. Morton and Chung (1959) have provided statistical evidence, based on the proportion of sporadic cases, which does not agree with the hypothesis of an autosomal trait with sex-limitation but does agree with that of $\mathrm{X}$-linkage. The fact that typical Duchenne muscular dystrophy has been described in two females with an XO sex chromosome con-

Received November 19, 1965. stitution (Walton, I957; Ferrier, Bamatter, and Klein, 1965) also suggests X-linkage.

With regard to the demonstration of linkage between the genes for Duchenne muscular dys으 trophy and the $\mathrm{X}$-linked marker traits, there are apparently no published reports concerning glucose 6-phosphate dehydrogenase (G6PD) deficiency, ando two recent studies indicate that the loci for the $\mathrm{Xg}_{\mathrm{g}}$ blood group and Duchenne muscular dystrophy ar: not closely linked (Clark, Puite, Marczynski, and Mann, 1963; Blyth, Carter, Dubowitz, Emeryo Gavin, Johnston, McKusick, Race, Sanger, ands Tippett, 1965). Linkage studies concerninge Duchenne muscular dystrophy and colour blindness have been reported in only one family where $§$ recombinants were found among 20 individual $\vec{\delta}$ (Philip, Walton, and Smith, 1956).

The present communication concerns the results of linkage studies of colour blindness and Duchenne muscular dystrophy in 4 families. Though the numbers are small, the results are reported in the hope that they might be usefully combined with? those of other investigators.

\section{Subjects and Methods}

All the affected boys in the present study had the severe Duchenne type of muscular dystrophy $\frac{}{0}$ Information on recombination has been obtained by studying the phenotypes of male offspring of doublyo heterozygous females. A woman was considere heterozygous for the gene for Duchenne musculat dystrophy if she had two or more affected sons or onew affected son but a family history of a brother or maternal male relative having been similarlye affected. All the sons, whether affected or unaffected of such a heterozygous female were tested for colour blindness and the $\mathrm{Xg}$ blood group. If the results suggested that the mother was doubly heterozygous then the maternal grandfather and sometimes other? maternal relatives were also tested. Since it is no\& 
possible to detect heterozygotes for colour blindness with certainty, sisters of affected males were not considered. Colour vision was tested using Ishihara plates, American Optical Hardy-Rand-Rittler pseudo-isochromatic plates, and the Tokyo Medical College plates. In only one case (III.5, Family L) was there any doubt regarding the type of defect using these tests, and in this case the Nagel anomaloscope was used, which clearly demonstrated that this boy was protan colour blind.

By using these various tests it seems that the majority of persons with defective colour vision can be detected (Kalmus, 1965). The $\mathrm{Xg}^{\mathrm{a}}$ antigen was tested for by Dr. Robert R. Race and Dr. Ruth Sanger (M.R.C. Blood Group Research Unit, The Lister Institute, London), on blood collected by venepuncture. In only one of the families reported here (family $\mathrm{H}$ ) were the $\mathrm{Xg}$ data informative.

\section{Results}

The genes for Duchenne muscular dystrophy and colour blindness were found to be segregating in four families, and in one family the gene for the $\mathrm{Xg}$ blood group was also segregating (family $\mathrm{H}$ ). The defect in colour vision was deutan in three families $(H, P$, and $R$ ) and protan in one family (L). The informative parts of the pedigrees are shown in the Figure.
In two of the families ( $H$ and $R$ ) it seems most likely that in the doubly heterozygous females the genes for Duchenne muscular dystrophy and colour blindness are in repulsion. In family $\mathrm{H}$, a sister of II.I has a son with Duchenne muscular dystrophy, but it has not been possible to investigate this side of the family. In family R, I.2 has a sister with 3 sons with Duchenne muscular dystrophy but they live in Canada and it has not been possible to study them. In family L, I.I was refused a job as a train driver because he was 'colour blind', a fact that was verified by his family doctor. In family P, I.I died in old age and did not have muscular dystrophy, nor is there a history of any other members of the family having had this disease. It is not known whether I.I was colour blind; the two brothers of II.I both have normal colour vision.

With regard to deutan colour blindness there are 3 recombinants out of a total of 7 scorable progeny (42.8\% recombinants). With regard to protan colour blindness there is I recombinant out of 3 scorable progeny $(33.3 \%$ recombinants) (Table).

In family $\mathrm{H}$, with regard to the genes for the $\mathrm{Xg}$ blood group and deutan colour blindness all 3 sons are recombinants. This family has been previously reported as part of a series concerning linkage between the genes for the $\mathrm{Xg}$ blood group and Duchenne muscular dystrophy (Blyth et al., 1965).
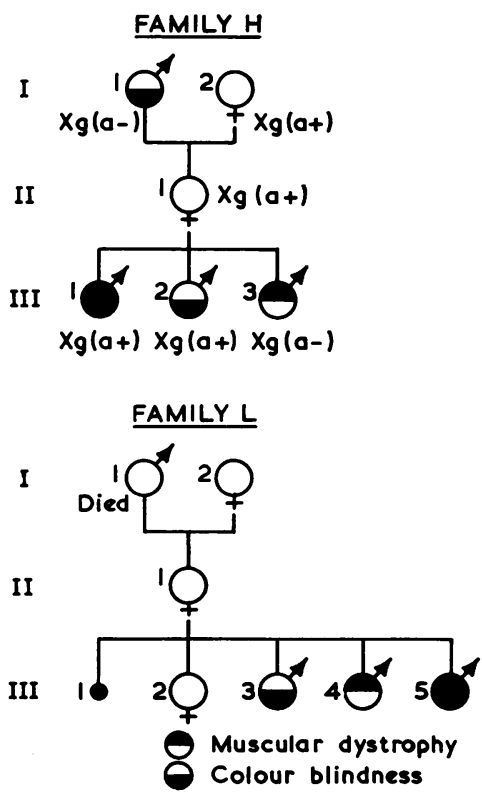
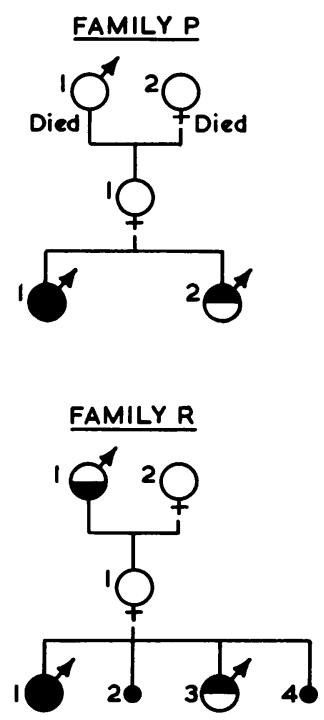

Doubly affected

Abortion

FIG. Informative parts of 4 families in which the genes for Duchenne muscular dystrophy and colour blindness are segregating. 
TABLE

TYPES OF COLOUR BLINDNESS AND MINIMUM NUMBER OF RECOMBINANT TYPES IN FAMILIES STUDIED

\begin{tabular}{c|c|c|c}
\hline Family & $\begin{array}{c}\text { Type of } \\
\text { Colour Blindness }\end{array}$ & Recombinants & Scorable Progeny \\
\hline $\mathbf{H}$ & Deutan & I (III.I) & 3 \\
$\mathbf{L}$ & Protan & I (III.5) & 3 \\
$\mathbf{P}$ & Deutan & I (?) & $\mathbf{2}$ \\
$\mathbf{R}$ & Deutan & I (III.I) & $\mathbf{2}$ \\
\hline
\end{tabular}

\section{Discussion}

Most female carriers of Duchenne muscular dystrophy appear to be perfectly healthy, and clinical manifestations of muscle disease are rare (Emery, 1966). The demonstration of close linkage between the genes for Duchenne muscular dystrophy and one of the X-linked marker traits (G6PD deficiency, the $\mathrm{Xg}$ blood group, and colour blindness) would be a great help in recognizing carriers and possibly preclinical cases of this disease. Unfortunately neither the $\mathrm{Xg}$ blood group locus nor the colour vision loci appear to be closely linked to the gene for Duchenne muscular dystrophy. With regard to the $\mathrm{Xg}$ blood group and Duchenne muscular dystrophy, analysis by the lod score method indicates that these two loci are far apart on the $\mathrm{X}$ chromosome: the lower confidence limit (I/20) of the recombination fraction is estimated to be 0.32 by Clark et al. (1963) and 0.35 by Blyth et al. (1965).

A family has been described in which the genes for Duchenne muscular dystrophy and 'incomplete red-green' colour blindness were segregating (Philip et al., 1956). Five recombinant types were found in 20 individuals, and using the method of maximum likelihood the recombination fraction was estimated to be $0.26 \pm 0.1$ I. Frézal, de Grouchy, Lamy, and Pognan (1957) also studied a family with muscular dystrophy and a defect in colour vision. Subsequent studies, however, have revealed that this was not an $\mathrm{X}$-linked form of muscular dystrophy (J. Frézal, I963, personal communication).

In this investigation genetic linkage studies have been carried out on 3 families with Duchenne muscular dystrophy and deutan colour blindness, and in one family with Duchenne muscular dystrophy and protan colour blindness. In families $\mathrm{H}$ and $\mathbf{R}$ the doubly heterozygous females are carriers of X-linked Duchenne muscular dystrophy because, besides their own sons, they have other male relatives affected with this condition. In families $L$ and $P$ the doubly heterozygous females both have two affected sons, but no one else in their families has been affected. In these cases there is the pos- sibility that this might be the autosomal recessive form of Duchenne muscular dystrophy which is clinically similar to the X-linked form (Dubowitz; 1960; Jackson and Carey, 196I). However, the likelihood of having two sons affected with $\frac{\pi}{8}$ hereditary condition is four times more likely if it is $\mathrm{X}$-linked than if it is an autosomal recessive; i addition over $90 \%$ of cases of Duchenne muscula dystrophy are due to the X-linked form of the disease (Lamy and de Grouchy, 1954; Emery, 1964\% For these reasons it is highly probable that the heterozygotes in families $\mathrm{L}$ and $\mathrm{P}$ are carriers of the $\mathrm{X}$-linked form of Duchenne muscular dystrophy. $\vec{\omega}$

In the present study, 3 recombinants out of total of 7 scorable progeny were found in the case of deutan colour blindness and I recombinant outt of 3 scorable progeny in the case of protan colout blindness. The numbers are too small for any conto clusions to be drawn regarding the apparens difference in the recombination fractions for the two types of colour vision defect. However, the results do agree with those of Philip et al. (1956) i showing that the genes for colour blindness and Duchenne muscular dystrophy are quite far aparof on the $\mathrm{X}$ chromosome and are not sufficiently close to be of any practical use in the recognition of the carrier state or the preclinical case of this disease.

\section{Summary}

Genetic linkage studies have been carried out o® 3 families with Duchenne muscular dystrophy and deutan colour blindness and in one family with Duchenne muscular dystrophy and protan colour blindness. Three recombinants out of a total of scorable progeny were found in the case of deutan colour blindness, and I recombinant out of a tota of 3 scorable progeny in the case of protan colous blindness.

Dr. Louise Sloan very kindly tested one of the patients with the Nagel anomaloscope.

\section{REFERENCES}

Becker, P. E. (1962). Two new families of benign sex-linked recessix

muscular dystrophy. Rev. canad. Biol., 21, 551.
Bell, J. (1948). On pseudohypertrophic and allied types of prô gressive muscular dystrophy. Treas. hum. Inherit., 4, 283.

Blyth, H., Carter, C. O., Dubowitz, V., Emery, A. E. H., Gavin, Johnston, H. A., McKusick, V. A., Race, R. R., Sanger, R., and Tippett, P. (1965). Duchenne's muscular dystrophy and the blood groups: a search for linkage. $\mathcal{F}$. med. Genet., 2, 157.

Clark, J. I., Puite, R. H., Marczynski, R., and Mann, J. D. (196\% Evidence for the absence of detectable linkage between the genes for Duchenne muscular dystrophy and the $\mathrm{Xg}$ blood grouf. Amer. F. hum. Genet., 15, 292.

Dubowitz, V. (I960). Progressive muscular dystrophy of the Duchenne type in females and its mode of inheritance. Brain, \& 432. 
Emery, A. E. H. (1964). Hereditary myopathies. Clin. Orthop., 33, 164 .

(1966). Carrier detection in sex-linked muscular dystrophy. 7. Génét. hum., 14, 318.

Ferrier, P., Bamatter, F., and Klein, D. (1965). Muscular dystrophy (Duchenne) in a girl with Turner's syndrome. 7. med. Genet., $2,38$.

Frézal, J., de Grouchy, J., Lamy, M., and Pognan, C. (I957). Myopathie et Daltonisme. Analyse d'un pedigree. Ann. hum. Genet., $21,237$.

Jackson, C. E., and Carey, J. H. (196r). Progressive muscular dystrophy: autosomal recessive type. Pediatrics, 28, 77.

Kalmus, H. (1965). Diagnosis and Genetics of Defective Colour Vision. Pergamon, Oxford.

Lamy, M., and de Grouchy, J. (1954). L'hérédité de la myopathie (formes basses). F. Génét hum., 3, 219.

Milhorat, A. T., and Wolff, H. G. (1943). Studies in diseases of muscle. Arch. Neurol. Psychiat. (Chic.), 49, 641.
Morton, N. E., and Chung, C. S. (1959). Formal genetics of muscular dystrophy. Amer. F. hum. Genet., II, 360.

Philip, U., Walton, J. N., and Smith, C. A. B. (1956). Colour blindness and the Duchenne type muscular dystrophy. Ann. hum. Genet., 21, 155.

Stephens, F. E., and Tyler, F. H. (195I). Studies in disorders of muscle. V. The inheritance of childhood progressive muscular dystrophy in 33 kindreds. Amer. F. hum. Genet., 3, III.

Stevenson, A. C. (1953). Muscular dystrophy in Northern Ireland. An account of the condition in 5I families. Ann. Eugen. (Lond.), 18, 50.

Walton, J. N. (1955). On the inheritance of muscular dystrophy. Ann. hum. Genet., 20, I.

(1957). The inheritance of muscular dystrophy. Acta genet. (Basel), 7, 318.

, and Nattrass, F. J. (1954). On the classification, natural history and treatment of the myopathies. Brain, 77, 169. 